\title{
Pertumbuhan dan Kadar Pigmen Dunaliella salina (Chlorophyta) pada Media dengan Penambahan Konsentrasi Tembaga $(\mathrm{Cu})$ yang Berbeda
}

\author{
Faiz Naida Salimah, Gunawan Widi Santosa*, Ali Ridlo \\ Departemen Ilmu Kelautan, Fakultas Perikanan dan Ilmu Kelautan, Universitas Diponegoro \\ Jl. Prof. Soedarto, SH, Tembalang, Semarang, Jawa Tengah 50275 Indonesia \\ Email: gunawan.ws60@gmail.com
}

\begin{abstract}
Abstrak
Dunaliella salina merupakan mikroalga hijau yang memiliki peran penting dalam rantai makanan di lingkungan perairan dan kandungan pigmennya telah banyak dimanfaatkan. Pertumbuhan dan kandungan biomolekul $D$. salina dipengaruhi oleh kondisi lingkungan hidupnya, salah satunya mikronutrien tembaga $(\mathrm{Cu})$. Penelitian ini bertujuan untuk mengetahui pengaruh konsentrasi $\mathrm{Cu}$ dalam media terhadap pertumbuhan dan kandungan pigmen $D$. salina. Penelitian ini menggunakan metode eksperimental dengan Rancangan Acak Lengkap (RAL) menggunakan 1 perlakuan dengan 4 taraf perlakuan (3 kali ulangan). Perlakuan yang diberikan adalah penambahan $\mathrm{Cu}$ dengan konsentrasi 1, 3, dan 5 ppm kedalam media kultur $D$. salina dan tanpa penambahan atau kontrol. Analisis kadar pigmen klorofil-a,b dan total karotenoid dilakukan menggunakan metode spektroskopi. Hasil penelitian menunjukkan bahwa penambahan konsentrasi $\mathrm{Cu}$ yang berbeda pada media memberikan pengaruh nyata $(\mathrm{p} \leq 0,05)$ terhadap laju pertumbuhan mikroalga dan kadar pigmen $D$. salina. Laju pertumbuhan tetinggi dicapai pada perlakuan B (penambahan $1 \mathrm{ppm}$ ) sebesar $0,44 \pm 0,03 \mathrm{sel} / \mathrm{hari}$ dan terendah pada perlakuan D (penambahan $5 \mathrm{ppm}$ )

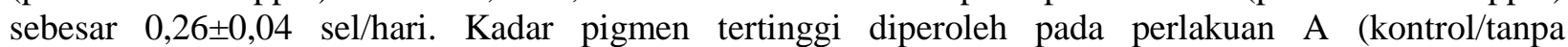
penambahan) dengan klorofil-a sebesar $18,04 \pm 1,80 \mu \mathrm{g} / \mathrm{mL}$, klorofil-b sebesar $9,03 \pm 0,87 \mu \mathrm{g} / \mathrm{mL}$, serta total karotenoid $5,66 \pm 0,80 \mu \mathrm{g} / \mathrm{mL}$ dan terendah pada perlakuan $\mathrm{D}$ (penambahan $5 \mathrm{ppm}$ ) dengan klorofil-a sebesar 7,56 $\pm 1,30 \mu \mathrm{g} / \mathrm{mL}$, klorofil-b 3,91 $\pm 0,90 \mu \mathrm{g} / \mathrm{mL}$ serta total karotenoid 2,12 $\pm 0,37 \mu \mathrm{g} / \mathrm{mL}$. Semakin tinggi konsentrasi $\mathrm{Cu}$ yang ditambahkan maka laju pertumbuhan dan kadar pigmen $D$. salina semakin menurun. Efek toksik $\mathrm{Cu}$ terhadap laju pertumbuhan dan kadar pigmen secara signifikan mulai terjadi dari penambahan 3 ppm Cu ke dalam media.
\end{abstract}

Kata kunci : Dunaliella salina, Pigmen, Pertumbuhan, Tembaga $(\mathrm{Cu})$

\section{Abstract \\ Growth and Pigment Levels of Dunaliella salina (Chlorophyte) on Media with the Addition of Different Copper (Cu) Concentration}

Dunaliella salina is a green microalga that has an important role in the food chain in aquatic environments and its pigment content has been widely utilized. The growth and content of biomolecules $D$. salina are influenced by environmental conditions, one of which is the micronutrient copper $(\mathrm{Cu})$. This study used an experimental method with a completely randomized design (CRD) using 1 treatment with 4 levels of treatment (3 replications). The treatment given was the addition of $\mathrm{Cu}$ with a concentration of 1 , 3 , and 5 ppm into the D. salina culture media and without addition or control. Analysis of the levels of chlorophyll-a, $b$, and total carotenoid pigments was carried out using a spectroscopic method. The results showed that the addition of different $C u$ concentrations in the media had a significant effect $(p \leq 0,05)$ on the growth rate of microalgae and the pigment levels of $D$. salina. The highest growth rate was achieved in treatment $B$ (addition of 1 ppm) of 0,44 $\pm 0,03$ cell/day and the lowest was in treatment $D$ (addition of 5 ppm) of 0,26 0,04 cell/day. The highest pigment content was obtained in treatment A (control) with

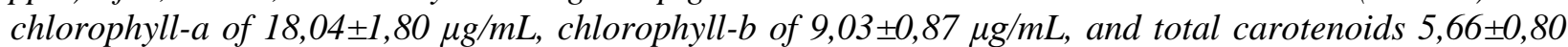
$\mu \mathrm{g} / \mathrm{mL}$ and the lowest in treatment $D$ (addition of $5 \mathrm{ppm}$ ) with chlorophyll-a of 7,56 $1,30 \mu \mathrm{g} / \mathrm{mL}$, 
chlorophyll-b 3,91 $\pm 0,90 \mu \mathrm{g} / \mathrm{mL}$ and total carotenoids $2,12 \pm 0,37 \mu \mathrm{g} / \mathrm{mL}$. The higher the $C u$ concentration was added, the lower the growth rate and pigment levels of D. salina. The toxic effect of $\mathrm{Cu}$ on the growth rate and pigment levels was significant from the addition of $3 \mathrm{ppm} \mathrm{Cu}$ into the media.

Keywords : Dunaliella salina, Pigment, Growth, Copper $(\mathrm{Cu})$

\section{PENDAHULUAN}

Dunaliella salina merupakan mikroalga hijau yang memiliki peran penting dalam rantai makanan dan sebagai produktivitas primer di laut (Purbonegoro, 2008). Mikroalga ini telah banyak dimanfaatkan dalam dunia perikanan sebagai pakan alami larva serta sebagai produk suplemen makanan, industri pangan, dan farmasi (Bawias et al., 2018). Pemanfaatan D. salina tidak lepas dari kandungan biokimianya seperti pigmen. Menurut Erlania (2009), D. salina mengandung $\beta$-karoten sebanyak $14 \%$ dari bobot keringnya sehingga dijadikan bahan fortifikasi pangan di Eropa.

Klorofil merupakan pigmen hijau yang memiliki peran sebagai penangkap cahaya, konversi cahaya dan transfer energi dalam proses fotosintesis dan menyerap gelombang maksimum antara 400 - $700 \mathrm{~nm}$ (Pratiwi et al., 2015). Terdapat dua jenis klorofil pada $D$. salina yaitu klorofil-a yang merupakan suatu pigmen aktif dalam fotosintesis dan klorofil-b yang memiliki peran penting dalam mekanisme fotosistem selama adaptasi terhadap intensitas cahaya. Klorofil-b diseintesis dari klorofil-a dengan bantuan enzim Chlorophyll-a oxidase (Song dan Banyo, 2011). Peran karotenoid dalam sel $D$. salina adalah membantu klorofil untuk menyerap cahaya dalam proses fotosintesis (Fretes et al., 2012). Karotenoid juga dapat menjadi fotoprotektor dengan mencegah terbentuknya triplet oksigen (klorofil berikatan dengan oksigen) sehingga oksigen tunggal tidak dihasilkan (Maleta et al., 2018). Menurut Fauziah et al. (2019), pigmen klorofil dan karoteid menjadi komponen penting di perairan karena digunakan sebagai biomarker kuantitatif untuk mengetahui komposisi dan kepadatan mikroalga di laut. Secara tidak langsung, hal tersebut dapat menjadi suatu ukuran dari pertumbuhan sel serta menjadi parameter yang digunakan untuk memeriksa kualitas suatu perairan.

Pertumbuhan dan kandungan pigmen yang disintetis oleh $D$. salina dipengaruhi oleh beberapa faktor lingkungan tempat hidupnya. Tembaga $(\mathrm{Cu})$ merupakan logam esensial sebagai mikronutrien $D$. salina yang berperan dalam aktivitas beberapa enzim pada sel, serta penyusun komponen rantai transport elektron dalam kloroplas dan mitokondria (Nikookar et al., 2005). Komponen dalam sel yang disusun atas $\mathrm{Cu}$ adalah plastocyanin dan beberapa enzim diantaranya polyphenol oxidase, superoxide dismutase, ascorbate oxidase, cytochrome oxidase, lysyl oxidase, and diamine oxidase (Nugroho dan Frank, 2011). Konsenrasi $\mathrm{Cu}$ yang berlebih dapat menyebabkan terganggunya proses metabolisme sel D. Salina dalam proses fotosintesis dan kemampuan sel untuk memperbanyak diri (Purbonegoro, 2008). Menurut Nugroho dan Frank (2011), selain mereduksi pertumbuhan dan kepadatan, $\mathrm{Cu}$ juga dapat mereduksi kandungan pigmen klorofil dan karotenoid karena terjadi kerusakan pada kloroplas.

Pesisir merupakan tempat yang rentan terhadap pencemaran di perairan karena menjadi tempat berkumpulnya zat-zat pencemar seperti limbah logam berat yang terbawa oleh aliran sungai. Limbah logam berat merupakan zat yang berbahaya karena sulit terdegradasi (Setiawan, 2014). Sumber $\mathrm{Cu}$ di perairan dapat berasal dari limbah buangan industri dan aktivitas pelabuhan. Semakin tinggi aktivitas pabrik dan kendaraan pelabuhan maka kadar $\mathrm{Cu}$ di perairan akan meningkat pula (Puryanti dan Anggraini, 2019). Menurut Peraturan Menteri Lingkungan Hidup Republik Indonesia Nomor 5 Tahun 2014, bahwa baku mutu air limbah dengan konsentrasi $\mathrm{Cu}$ adalah $2-3$ ppm. Berdasarkan penelitian sebelumya, pada kisaran konsentrasi $1-5$ ppm $\mathrm{Cu}$ dapat mempengaruhi pertumbuhan mikroalga Spirulina plantesis (Budi et al., 2018), dan menurunkan kadar pigmen pada mikroalga Phorpyridium cruentum (Pranajaya et al., 2014), dan Chaetoceros sp. (Puspitasari et al., 2017).

D. salina termasuk spesies mikroalga yang memiliki habitat dengan kisaran salinitas, suhu, dan $\mathrm{pH}$ yang luas serta memiliki toleransi tinggi terhadap perubahan kondisi lingkungan (Kutlu dan Mutlu, 2017). Sendra et al. (2018), melaporkan bahwa spesies ini lebih toleran terhadap logam perak (Ag) dibandingkan dengan Chlorella autotrophica. Menurut Ghazaei dan 
Shariati (2019), D. Salina juga lebih toleran terhadap titanium (Ti) daripada $D$. tertiolecta. Berdasarkan hal tersebut, maka perlu dilakukan penelitian untuk mengetahui bagaimana pengaruh $\mathrm{Cu}$ terhadap pertumbuhan dan kadar pigmen $D$. salina. Tujuan penelitian ini adalah untuk mengetahui pengaruh penambahan konsentrasi $\mathrm{Cu}$ yang terbeda terhadap laju pertumbuhan dan kadar pigmen (klorofil-a, klorofil-b dan total karotenoid) mikroalga $D$. salina.

\section{MATERI DAN METODE}

Biota uji yang digunakan adalah biakan murni mikroalga $D$. salina yang diperoleh dari Laboratorium Balai Besar Pengembangan Budidaya Air Payau (BBPBAP) Jepara sebanyak 1,5 liter.

D. salina dikultur ke dalam 12 botol kaca steril berkapasitas 1 liter menggunakan kultur 500 $\mathrm{mL}$. Media kultur yang digunakan adalah air laut steril bersalinitas $30 \mathrm{ppt}$ yang diperkaya dengan pupuk Walne $1 \mathrm{~mL} / \mathrm{L}$ dan vitamin $0,5 \mathrm{~mL} / \mathrm{L}$ dan ditambahkan $\mathrm{CuSO}_{4} .5 \mathrm{H}_{2} \mathrm{O}$ p.a Merck dengan konsentrasi $\mathrm{Cu}$ mengacu pada penelitian Budi et al. (2018), yakni A (kontrol/tanpa penambahan), $\mathrm{B}$ (penambahan $1 \mathrm{ppm}), \mathrm{C}$ (penambahan $3 \mathrm{ppm}$ ) dan D (penambahan 5 ppm). Selanjutnya biakan murni D. salina diinokulasikan kedalam masingmasing botol kaca dengan kepadatan awal $1 \times 10^{6}$ $\mathrm{sel} / \mathrm{mL}$ dengan terus diaerasi dan diinkubasi pada suhu $23-25{ }^{\circ} \mathrm{C}$. Pencahayaan menggunakan lampu TL Philips 36 Watt dengan intensitas 2.000 lux menggunakan manipulasi durasi gelap:terang masing-masing 12 jam. Inkubasi dilakukan selama 8 hari.

Kepadatan sel dihitung menggunakan haemocytometer dengan rumus menurut Gunawan dan Wianto (2016):

$$
D=N \times 10^{4}
$$

Keterangan : $\mathrm{D}=$ kepadatan mikroalga $(\mathrm{sel} / \mathrm{mL})$; $\mathrm{N}=$ jumlah keseluruhan sel mikroalga terhitung dibagi oleh jumlah blok terhitung.

Laju pertumbuhan dihitung selama fase eksponensial dengan rumus menurut Fakhri et al. (2020):

$$
\mu=\frac{\ln x 2-\ln x 1}{t 2-t 1}
$$

Keterangan : $\mu=$ laju pertumbuhan spesifik per unit kepadatan (sel/hari); $\mathrm{x} 1=$ kepadatan pada waktu ke-1; $\mathrm{x} 2=$ kepadatan pada waktu ke-2; $\mathrm{t} 1=$ waktu ke-1; t2= waktu ke-2.

\section{Analisis Kadar Pigmen}

Analisi kadar pigmen dilakukan pada akhir fase awal stasioner menggunakan metode Pisal dan Lele (2005). Ektraksi dilakukan dengan mengambil $5 \mathrm{~mL}$ alikuot dari suspensi $D$. salina, kemudian disentrifugasi pada kecepatan 3000 rpm selama 10 menit. Supernatan dibuang dan endapan mikroalga dimaserasi menggunakan 5 $\mathrm{mL}$ larutan aseton 80\% (v/v) p.a Merck selama 12 jam. Setelah itu disentrifugasi kembali untuk mendapatkan supernatan yang kemudian dianalisis menggunakan spektrofotometer UV-Vis dengan panjang gelombang $470 \mathrm{~nm}, 646,8 \mathrm{~nm}$, dan 663,2 $\mathrm{nm}$. Kadar pigmen dihitung menggunakan rumus Lichtenthaler dan Buchmann (2001):

$$
\begin{gathered}
C_{a}=12,25 A_{663,2}-2,79 A_{646,8} \\
C_{b}=21,50 A_{646,8}-5,10 A_{663,2} \\
C_{x+c}=\frac{1000 A_{470}-1,82 C_{a}-85,02 C_{b}}{198}
\end{gathered}
$$

Keterangan : $\mathrm{C}_{\mathrm{a}}=$ kadar klorofil a $(\mu \mathrm{g} / \mathrm{mL}) ; \mathrm{C}_{\mathrm{b}}=$ kadar klorofil b $(\mu \mathrm{g} / \mathrm{mL}) ; \mathrm{C}_{\mathrm{x}+\mathrm{c}}=$ kadar total karotenoid $(\mu \mathrm{g} / \mathrm{mL})$.

\section{Analisis Data}

Data laju pertumbuhan dan kadar pigmen klorofil-a, klorofil-b dan total karotenoid diolah menggunakan Microsoft Excel dan SPSS 16.0. Uji Anova satu arah dan Uji Tukey dilakukan untuk mengetahui adanya pengaruh nyata dari satu variabel dan melihat letak perbedaan signifikan antar perlakuan. Besarnya pengaruh perlakuan diuji dengan Regresi Linier Sederhana.

\section{HASIL DAN PEMBAHASAN}

Mikroalga $D$. salina dapat tumbuh di semua kondisi perlakuan penambahan $\mathrm{Cu}$, namun terjadi perbedaan pada pola pertumbuhan dan kepadatan sel yang dihasilkan. Hasil pengamatan terhadap pencapaian kepadatan $D$. salina selama 8 hari diperoleh kepadatan sel seperti yang disajikan pada Gambar 1. Nilai kepadatan puncak tertinggi pada hari ke-8 perlakuan B (penambahan $1 \mathrm{ppm}$ ) sebesar $29,61 \times 10^{6} \pm 0,75 \mathrm{sel} / \mathrm{mL}$, sedangkan kepadatan puncak terendah pada hari ke-4 perlakuan D (penambahan $5 \mathrm{ppm}$ ) sebesar $8,15 \mathrm{x}$ $10^{6} \pm 0,57 \mathrm{sel} / \mathrm{mL}$.

Pertumbuhan sel mikroalga berbanding lurus dengan kepadatan sel. Laju pertumbuhan $D$. salina tertinggi dicapai oleh perlakuan B (penambahan $1 \mathrm{ppm}$ ) sebesar $0,44 \pm 0,03 \mathrm{sel} / \mathrm{hari}$ dan terendah pada perlakuan D (penambahan 5 
ppm) sebesar 0,26 $\pm 0,04$ sel/hari. Besarnya nilai laju pertumbuhan dapat menggambarkan tingkat keberhasilan mikroalga dalam beradaptasi terhadap lingkungannya (Regista et al., 2017). Berdasarkan hasil tersebut diduga bahwa penambahan $\mathrm{Cu}$ dengan konsentrasi $1 \mathrm{ppm}$ dibutuhkan oleh mikroalga $D$. salina sebagai nutrisi untuk pertumbuhannya. Menurut Akbarnezhad et al. (2017), $\mathrm{Cu}$ pada konsentrasi rendah dapat menstimulasi IAA (Indole Acetic Acid), suatu hormon yang mampu untuk merangsang pertumbuhan.

Berdasarkan Uji ANOVA satu arah konsentrasi penambahan $\mathrm{Cu}$ yang berbeda pada media memberikan pengaruh nyata $(p \leq 0,05)$ terhadap laju pertumbuhan D. salina. Hasil Uji Tukey pada perlakuan B (penambahan $1 \mathrm{ppm}$ ) dan $\mathrm{C}$ (penambahan $3 \mathrm{ppm}$ ) memiliki nilai yang tidak berbeda nyata terhadap perlakuan A (kontrol/tanpa penambahan), namun berbeda nyata terhadap perlakuan D (penambahan $5 \mathrm{ppm}$ ). Hal ini menunjukkan bahwa efek toksik $\mathrm{Cu}$ mulai terjadi pada penambahan $5 \mathrm{ppm}$ dengan menyebabkan penurunannya laju pertumbuhan $D$. salina secara signifikan. Semakin tinggi konsentrasi $\mathrm{Cu}$ yang ditambahkan pada media maka laju pertumbuhan $D$. salina semakin menurun $\left(y=-0,056 x+0,524 ; \mathrm{R}^{2}=0,667\right)$. Pengaruh $\mathrm{Cu}$ terhadap laju pertumbuhan sebesar $66,7 \%$.

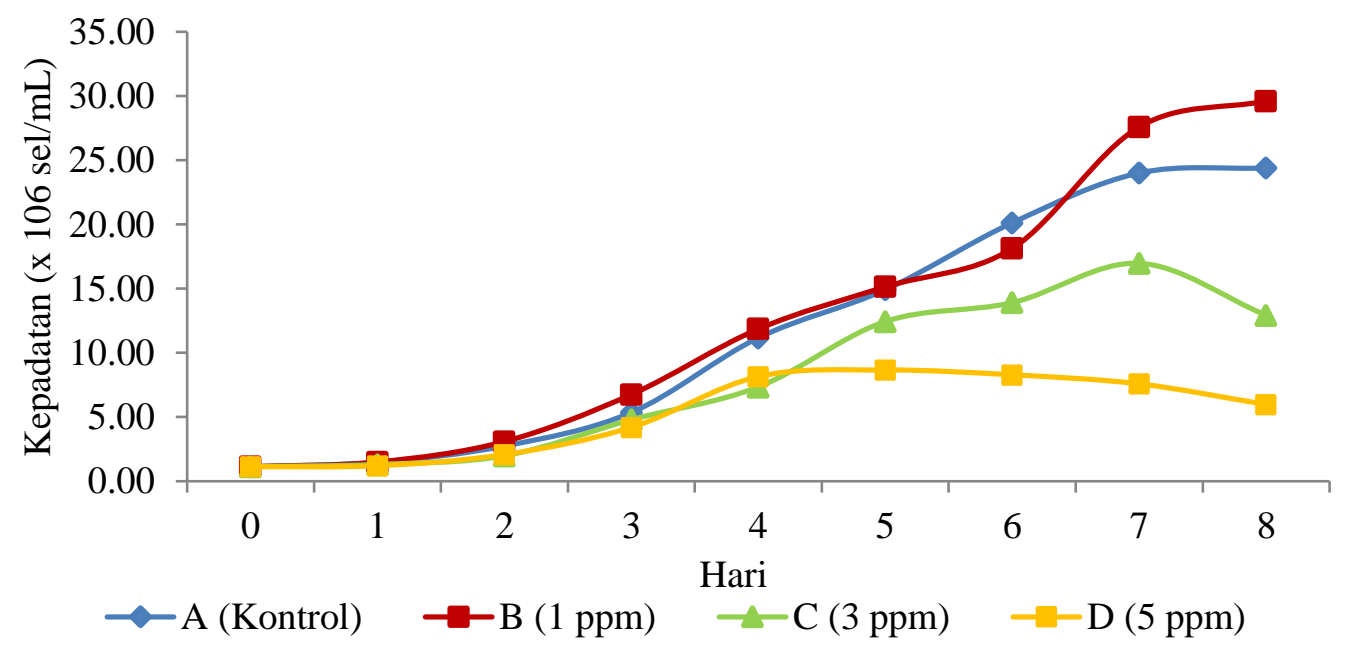

Gambar 1. Kepadatan D. salina pada Media dengan Penambahan Konsentrasi Cu yang Berbeda

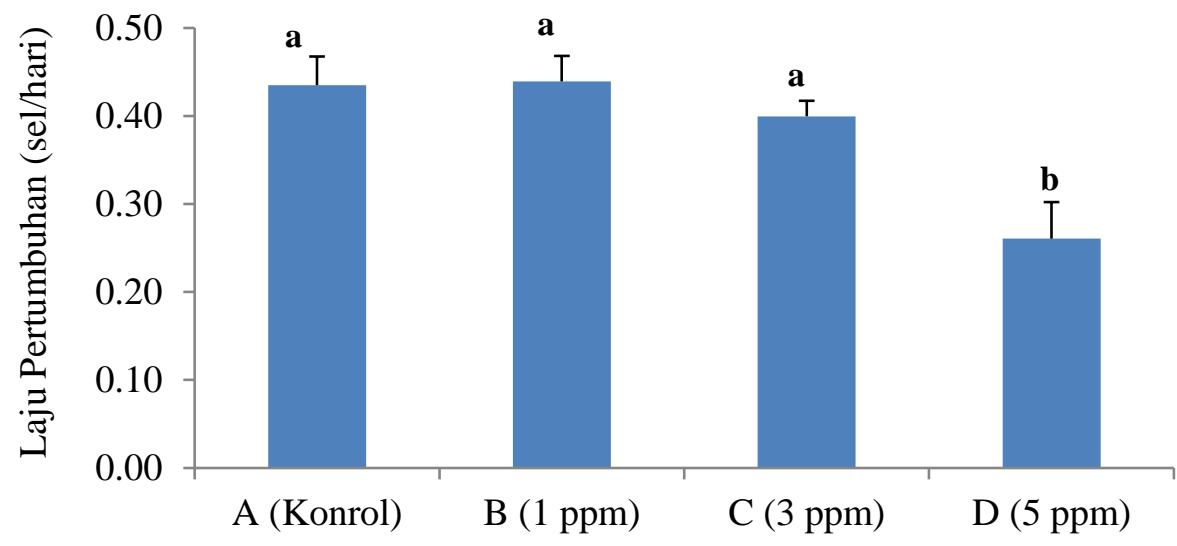

Penambahan Konsentrasi $\mathrm{Cu}$

Gambar 2. Pengaruh Perbedaan penambahan konsentrasi $\mathrm{Cu}$ yang berbeda terhadap laju pertumbuhan D.salina (Ket : Penambahan Huruf yang Berbeda Menunjukkan Nilai Berbeda Nyata pada $\alpha=0,05)$ 
Interaksi $\mathrm{Cu}$ dengan mikroalga berawal dari pengikatan ion $\mathrm{Cu}^{2+}$ pada dinding sel yang memiliki lapisan eksternal dengan muatan negatif seperti ion $\mathrm{OH}^{-}$. Mikroalga $D$. salina memiliki kemampuan pertukaran dan pengikatan ion $\mathrm{Cu}^{2+}$ karena pada membran selnya yang mengandung berbagai macam variasi polisakarida dan protein yang memiliki sisi aktif (Purnamawati et al., 2013). Ion $\mathrm{Cu}^{2+}$ akan bermigrasi melalui membran plasma lalu masuk kedalam sel dengan proses difusi atau penyerapan aktif. Ketika $\mathrm{Cu}^{2+}$ berada di dalam sitoplasma akan menyebabkan terganggunya transport elekron pada bagian feredoksin dari fotosistem, sehingga mempengaruhi proses fotosintesis dan pembelahan sel (Kumar dan Shin, 2017). Menurut Gunawan dan Wianto (2016), kematian sel mikroalga berawal dari kerusakan struktur kloroplas, lalu menghambat proses fotosintesis sehingga menurunkankemampuan sel mikroalga untuk memperbanyak diri.

\section{Kadar Pigmen D. salina}

Pemberian konsentrasi $\mathrm{Cu}$ yang berbeda juga memberikan pengaruh nyata $(p \leq 0,05)$ terhadap kadar pigmen klorofil-a, klorofil-b dan total karotenoid D. salina. Kadar pigmen tertinggi diperoleh pada perlakuan A (kontrol/tanpa penambahan) (Gambar 4). Mikroalga D. salina pada perlakuan kontrol tanpa penambahan $\mathrm{Cu}$ dalam media dapat tumbuh secara normal. Pupuk Walne memiliki kandungan $\mathrm{Cu}$ sebagai trace metal dalam konsentrasi yang rendah sehingga diasumsikan bahwa $\mathrm{Cu}$ dari pupuk Walne sudah mencukupi nutrisi yang diperlukan oleh D. salina. Perlakuan kontrol tanpa penambahan $\mathrm{Cu}$ menunjukkan pertumbuhan yang optimal dengan kadar pigmen yang dihasilkan nilai yang paling tinggi. Konsentrasi $\mathrm{Cu}$ dari pupuk Walne pada media kontrol tanpa penambahan adalah 0,005 ppm. Penurunan kadar pigmen secara signifikan mulai terjadi pada penambahan konsentrasi 3 ppm $\mathrm{Cu}$. Hal tersebut dibuktikan dari uji lanjutan Tukey pada perlakuan A (kontrol/tanpa penambahan) dan B (penambahan 1 ppm) yang memiliki nilai yang berbeda nyata $(p \leq 0,05)$ terhadap perlakuan $\mathrm{C}$ (penambahan $3 \mathrm{ppm}$ ) dan $\mathrm{D}$ (penambahan $5 \mathrm{ppm}$ ). Logam $\mathrm{Cu}$ akan menjadi toksik ketika dalam konsentrasi berlebih (ParalesVela et al., 2006).

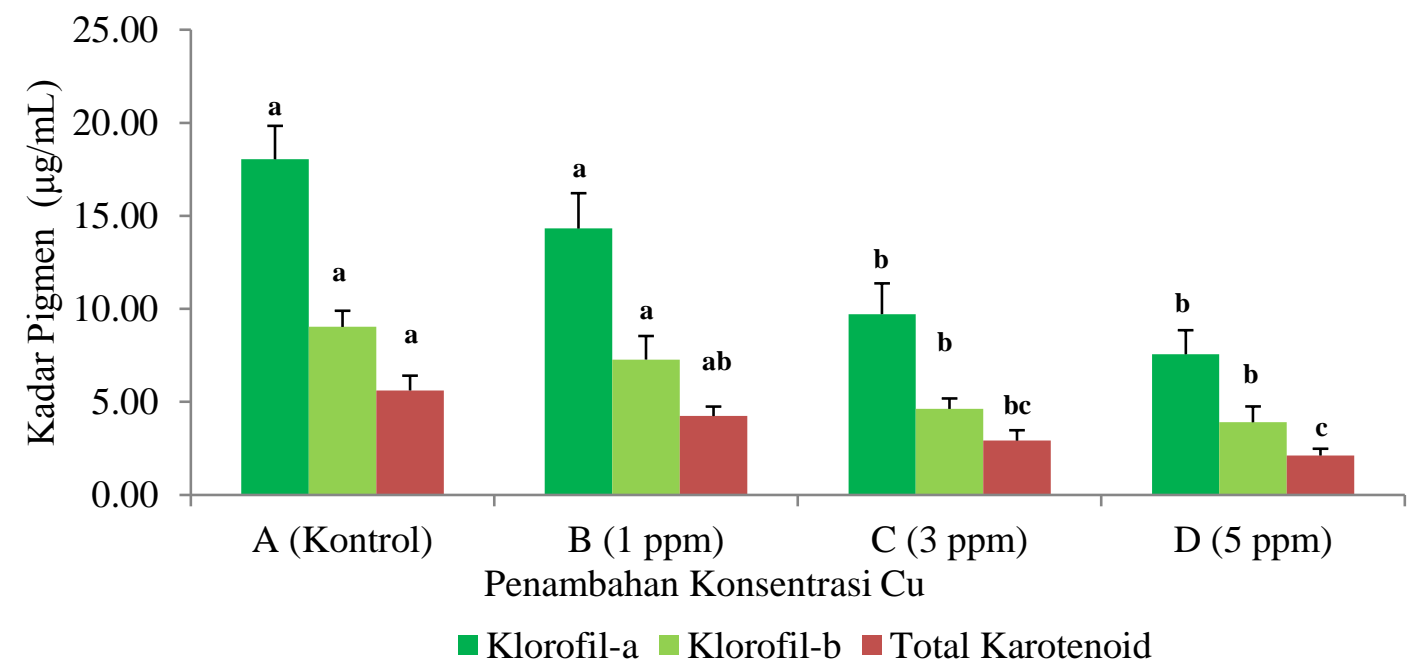

Gambar 3. Pengaruh Penambahan Konsentrasi $\mathrm{Cu}$ yang berbeda terhadap Kadar Pigmen D. salina (Ket. : Penambahan Huruf yang Berbeda Menunjukkan Nilai Berbeda Nyata pada $\alpha=0,05$ )

Tabel 1. Pengaruh Konsentrasi Penambahan $\mathrm{Cu}$ yang Berbeda Terhadap Kadar Pigmen D. salina $(\mu \mathrm{g} / \mathrm{mL} \pm \mathrm{SD}, \mathrm{n}=3)$

\begin{tabular}{cccccc}
\hline Kadar Pigmen & A & B & C & D & Regresi \\
\hline Klorofil-a & $18,04 \pm 1,80$ & $14,32 \pm 1,90$ & $9,76 \pm 1,66$ & $7,56 \pm 1,30$ & $\mathrm{y}=-3,604 x+21,417 ; \mathrm{R}^{2}=0,882$ \\
Klorofil-b & $9,03 \pm 0,87$ & $7,28 \pm 1,27$ & $4,62 \pm 0,56$ & $3,91 \pm 0,90$ & $\mathrm{y}=-1,845 \mathrm{x}+10,795 ; \mathrm{R}^{2}=0,864$ \\
Total & $5,62 \pm 0,80$ & $4,25 \pm 0,51$ & $2,29 \pm 0,53$ & $2,12 \pm 0,37$ & $\mathrm{y}=-1,182 \mathrm{x}+6,677 ; \mathrm{R}^{2}=0,876$ \\
Karotenoid & & & & & \\
\hline
\end{tabular}


Semakin tinggi konsentrasi $\mathrm{Cu}$ yang diberikan maka semakin rendah kadar pigmen yang dihasilkan (Tabel 1). Hasil penelitian tersebut diduga karena terdapat sensitivitas kloroplas pada $D$. salina terhadap $\mathrm{Cu}$ yang mengakibatkan penurunan kadar pigmen. Hal tersebut sesuai dengan pernyataan Pranajaya et al. (2014), bahwa $\mathrm{Cu}$ dapat menghambat proses biosintesis pigmen, mempercepat dekomposisi pigmen dan merusak struktur fungsi kloroplas. Menurut Rai et al. (2016), kelebihan $\mathrm{Cu}$ dapat menyebabkan peroksidasi lipid dalam membran fotosintetik yang mempengaruhi sintesis dan degradasi pigmen fotosintesis. Selain itu, $\mathrm{Cu}$ juga mengganggu susunan membran tilakoid dan mengubah ultrastruktur kloroplas secara keseluruhan, menghambat transpor elektron fotosintetik dari PS I dan PS II, dan menghambat aktivitas RuBP karboksilase.

Hasil penelitian menunjukkan juga bahwa kepadatan sel yang tinggi tidak diikuti dengan kadar pigmen yang tinggi, diduga karena mikroalga mempertahankan diri dari efek tosik $\mathrm{Cu}$ dengan cara memperbanyak jumlah sel. Menurut Parales-Vela (2006), mikroalga menjaga integritas sel dengan mengaktifkan proses metabolisme yang berkaitan dengan pertumbuan sel untuk menghindari efek toksik $\mathrm{Cu}$.

Pigmen karotenoid berguna untuk melindungi sel mikroalga dari reaksi oksidatif serta sebagai pertahanan diri pada kondisi stress (Fretes et al., 2012). Keberadaan $\mathrm{Cu}$ berlebih akan meningkatkan toksisitas di lingkungan sehingga menyebabkan stress pada $D$. Salina, namun pada penelitian ini peningkatan konsentrasi $\mathrm{Cu}$ tidak diikuti dengan peningkatan total karotenoid sebagai pertahanan diri dari $\mathrm{Cu}$. Hal tersebut dapat diduga karena $D$. salina menghasilkan beberapa enzim sebagai pereda reaksi oksidatif. Efek toksik $\mathrm{Cu}$ sebagian terkait dengan produksi ROS (Reactive Oxygen Species), di antaranya adalah radikal superoksida $\left(\mathrm{O}_{2}{ }^{*}\right)$ (Adams et al., 2016). Enzim antioksidan seperti Superoksida Dismutase (SOD) dan katalase (CAT) memainkan peran kunci dalam penghilangan spesies oksigen reaktif yang diproduksi dalam sel mikroalga selama berbagai respon stres fisik-kimiawi. Sistem SOD-CAT memberikan pertahanan pertama terhadap toksisitas oksigen (El-Din, 2016). Selain itu terdapat enzim APX (Ascorbate Peroxidase) yang juga terlibat dalam pertahanan diri ini (Nikookar et al., 2005).

\section{KESIMPULAN}

Penambahan konsentrasi $\mathrm{Cu}$ yang berbeda pada media memberikan pengaruh nyata $(p \leq 0,05)$ terhadap laju pertumbuhan dan kadar pigmen $D$. salina. Semakin tinggi konsentrasi $\mathrm{Cu}$ yang ditambahkan maka laju pertumbuhan dan kadar pigmen D. salina semakin menurun. Efek toksik $\mathrm{Cu}$ terhadap laju pertumbuhan dan kadar pigmen secara signifikan mulai terjadi dari penambahan 3 ppm $\mathrm{Cu}$ ke dalam media.

\section{DAFTAR PUSTAKA}

Akbarnezhad, Mehrgan, M., Kamali, S.A. \& Baboli, J. 2017. Effect of Microelements (Fe, $\mathrm{Cu}, \mathrm{Zn}$ ) on Growth and Pigment Contents of Arthrospira (Spirulina) platesis. Iranian Journal of Fisheries Science, 19(2):653-668. doi: 10.22092/ijfs.2019.120614

Bawias, M., Kemer, K., Mantiri,D.M.H., Kumampung, D.R., Paransa, D.S.J., \& Mantiri, R. 2018. Isolasi Pigmen Karotenoid pada Mikroalga Nannochloropsis sp. dengan Menggunakan Beda Pelarut. Jurnal Pesisir Laut Tropis, 2(1):1-8. doi: 10.35800/jplt.6.2. 2018.20641.

Budi, M.R.S., Rahardja, B.S. \& Masithah, E.D. 2018. Potensi Penurunan Konsentrasi Logam Berat Tembaga $(\mathrm{Cu})$ dan Pertumbuhan Mikroalga Spirulina plantesis pada Media Kultur. Jurnal Akuakultur Rawa Indonesia, 6(1):83-93. doi: 10.36706/jari.v6i1.7152

El-Din, S.M.M. 2016. Effect of Heavy Metals (Copper, Cobalt and Lead) on Growth of Photosynthetic Pigments of the Green Alga Chlorella pyrenoidosa $\mathrm{H}$. Chick. Catrina: The International Journal of Environmental Sciences, 15(1):1-10.

Erlania. 2009. Prospek Pemanfaatan Mikroalga sebagai Sumber Pangan Alternatif dan Bahan Fortifikasi Pangan. Media Akualkultur, 4(1):59-66. doi: 10.15578/ma.4.1.2009.59-66

Fakhri, M., Antika, P.W., Ekawati, A.W. \& Arifin, N.B. 2020. Pertumbuhan, Kandungan Pigmen, dan Protein Spirulina plantesis yang dikultur pada $\mathrm{Ca}\left(\mathrm{NO}_{3}\right)$ dengan Dosis yang Berbeda. Journal of Aquaculture and Fish Health, 9(1):38-47. DOI: 10.20473/jafh.v9i1

Fauziah, A., Bengen, D.G., Kawaroe, M., Effendi, H. \& Krisanti, M. 2019. Hubungan Antara Ketersediaan Cahaya Matahari dan Konsentrasi Pigmen Fotosintetik di Perairan 
Selat Bali. Jurnal Ilmu dan Teknologi Kelautan Tropis, 11(1):37-48. doi: 10.29244/ jitkt.v11i1.23108

Fretes, H., Susanto, AB., Prasetyo, B. \& Limantara, L. 2012. Karetonoid dari Mikroalgae dan Mikroalgae: Potensi Kesehatan, Aplikasi dan Bioteknologi. Jurnal Teknologi dan Industri Pangan, 23(2):221228. doi: 10.6066/jtip.2012.23.2.221

Ghazaei, F. \& Shariati, M. 2019. Effects of Titanium Nanoparticles on the Photosynthesis, Respiration, and Physiological Parameters in Dunaliella salina and Dunaliella tertiolecta. Protoplasma, 257(1):75-88. doi: 10.1007/s00 709-019-01420-z

Gunawan \& Wianto, T. 2016. Respon Pertumbuhan Mikroalga indigenous Synechococcus sp. dan Penurunan Konsentrasi Logam Berat Fe pada Media Kultur. Prosiding Seminar Nasional Lahan Basah, 1:244-249.

Maleta, M.S., Indrawati, R., Limantara, L. \& Brotosudarmo, T.H.P. 2018. Ragam Metode Ekstraksi Karotenoid dari Sumber Tumbuhan dalam Dekade Terakhir. Jurnal Rekayasa Kimia dan Lingkungan, 13(1):40-50. doi: 10.23955/rkl.v13i1.10008

Kumar, K.S. \& Shin, K.H. 2017. Effect of Copper on Marine Microalga Tetraselmis suecica and its Influence on Intra- and Extracellular Iron and Zinc Content. Korean Journal of Ecology and Environment, 50(1):16-28. doi: 10.11614/KSL.2017.50.1.016

Kutlu, B. \& Mutlu, M. 2017. Growth and Bioaccumulation of Cadmium, Zinc, Lead, Copper in Dunaliella sp. Isolated from Homa Lagoon, Eastern Aegean Sea. Indian Journal of Geo Marine Science, 46(6):1162-1169.

Lichtenthaler, H.K. \& Buschmann, C. 2001. Chlorophylls and Carotenoids: Measurement and Characterization by UV-VIS Spectroscopy. Current Protocols in Food Analytical Chemistry, 1(1):F4.3.1-F4.3.8. doi: 10.1002/0471142913.faf0403s01

Nikookar, K., Moradshahi, A. \& Hosseini, L. 2005. Physiological Responses of Dunaliella tertiolecta to Copper Toxicity. Biomolecular Enginering, 22(4): 141-146. doi: 10.1016/j. bioeng.2005.07.001.

Nugroho, A.P. \& Frank, H. 2011. Producing Culoaded Algae for Feeding Experiment: Effect of Copper on Parachlorella kessleri.
Toxicology and Environmental Chemistry, 93(3):537-548. doi:10.1080/02772248. 2010. 537859

Parales-Vela, H.V., Gonzalez-Moreno, S. C., Montez-ecasitas, \& Canizarez-Villanueva, R. O. 2006. Growth, Photosynthetic and Respiratory Responses to Sub-lethal Copper Concentrations in Scenedesmus incrassatulus (Chlorophyceae). Chemosphere, 67(11): 22742281. doi:10.1016/j.chemosphere.2006.11.0 36

Pisal, D.S. \& Lele, S.S. 2005. Carotenoid Production from Microalgae Dunaliella salina. Indian Journal of Biotechnology, 4:476-483.

Pranajaya, R.H., Djunaedi, A. \& Yulianto, B. 2014. Pengaruh Tembaga Terhadap Kandungan Pigmen dan Pertumbuhan Mikroalga Merah Porphyridium cruentum. Ilmu Kelautan, 19(2):97-104. doi: 10.14710/ik.ijms.19.2.97-104

Pratiwi, R., Wahyuni, N. \& Alimuddin, A.H. 2015. Uji Fotostabilitas $\mathrm{TiO}_{2}$-Klorofil dari Mikroalga (Chlorella sp.). Jurnal Kimia Khatulistiwa, 4(3):56-64.

Purbonegoro, T. 2008. Pengaruh Logam Kadmium (Cd) terhadap Metabolisme dan Fotosintesis di Laut. Oseana, 33(1):25-31.

Purnamawati, F.S., Soeprabwati, T.R., \& Izzati, M. 2013. Pertumbuhan Chlorella vulgaris Beijerinck dalam Medium yang Mengandung Logam Berat $\mathrm{Cd}$ Dan $\mathrm{Pb}$ Skala Laboratorium. Prosiding Seminar Nasional Biologi. Semarang. 14 September 2013.

Puryanti, D. \& Angraini, W. 2019. Identifikasi Pencemaran Logam Berat Tembaga $(\mathrm{Cu})$, Timbal $(\mathrm{Pb})$ dan Kadmium (Cd) Air Laut di Sekitar Pelabuhan Teluk Bayur Kota Padang. Jurnal Ilmu Fisika, 11(2):95-101. doi: 10.25077/jif.11.2.95-101.2019

Puspitasari, R., Suratno, S., Purbonegoro, T., \& Agustin, A.T. 2017. Cu Toxicity on Growth and Chlorophyll-a of Chaetoceros sp. IOP Conference Series: Earth and Environmental Science 118. Bandung. 19 Oktober 2017. doi: 10.1088/1755-1315/118/1/012061

Rai, R., Agrawal, M., \& Agrawal, S.B. 2016. Impact of Heavy Metals on Physiological Processes of Plants: With Special Reference to Photosynthetic System. Plant Responses to Xenobiotics, 127-140. doi:10.1007/978-98110-2860-1_6

Regista, R., Ambeng, A., Litaay, M., \& Umar, M.R. 2017. Pengaruh Pemberian Vermikompos Cair Lumbricus rubellus Hoffmeister pada Pertumbuhan Chlorella sp. Bioma: Jurnal Biologi Makassar, 2(1):1-8. 
Sendra, M., J. Blasco and C.V.M. Araujo. 2018. Is the Cell Wall of Marine Phytoplankton a Protective Barrier or a Nanoparticle Interaction Site? Toxicological Responses of Chlorella autotrophica and Dunaliella salina to $\mathrm{Ag}$ and $\mathrm{CeO}_{2}$ Nanoparticles. Ecological Indicator, 95(2):1053-1067. doi: 10.1016/j. ecolind.2017.08.050

Setiawan, H. 2014. Pencemaran Logam Berat di Perairan Pesisir Kota Makassar dan Upaya
Penanggulangannya. Info Teknis Eboni, 11(1):1-13.

Song, A.N. \& Banyo, Y. 2011. Konsentrasi Klorofil Daun Sebagai Indikator Kekurangan Air pada Tanaman. Jurnal Ilmiah Sains, 11(2):166-172. doi: 10.35799/jis.11.2.2011.202 